\title{
Response of Blended Fertilizers on the Yield and Yield Components of some Horticultural and Field Crops in the Case of Ethiopia: A Review
}

\author{
Ewnetu Teshale*, Afework Legesse \\ Ethiopian Institute of Agricultural Research, Jimma Agricultural Research Center, P. O. Box 192, Jimma, \\ Ethiopia
}

*Corresponding Authors: Ewnetu Teshale, Ethiopian Institute of Agricultural Research, Jimma Agricultural Research Center, P. O. Box 192, Jimma, Ethiopia

\begin{abstract}
In Ethiopia Urea and DAP (di-ammonium phosphate) are the only fertilizer sources that have been in use for the past four decades in the country with blanket recommendation (100kg DAP and $100 \mathrm{Kg}$ urea ha-1). This blanket recommendation often fails to take into consideration differences in resource endowment (soil type, labor capacity, climate risk) or make allowances for dramatic changes in input/output price ratio, thereby discouraging farmers from fertilizer application.

Since absence of one or more nutrients $P, S, B$ and $\mathrm{Zn}$ besides $N$ and $P$ can depress yield significantly this could explain, in part, the modest crop yield improvements observed over the last few decades in contrast to significant increases in fertilizer use and investment made in the country. Today, in addition to $N$ and $P, S, B$ and $\mathrm{Zn}$ deficiencies are widespread in Ethiopian soils, while some soils are also deficient in $K$,

To overcome the constraint Balanced fertilizers containing $N, P, K, S, B$ and $\mathrm{Zn}$ in blend form are recommended for ameliorating site specific nutrient deficiencies and thereby increasing productivity. This review part was mainly focused on the newly blended fertilizers response on the growth and crop yield of different horticultural and field crops that was produced in the country.
\end{abstract}

Keywords: blended fertilizer, crop, grain yield, nutrient, soil

\section{INTRODUCTION}

In Ethiopia, fertilizer use trend has been focused mainly on the use and application of nitrogen and phosphorous fertilizers in the form of Di-ammonium phosphate (DAP) (18-46-0) and Urea (46-0-0) or blanket recommendation for the major food crops. The previous result indicated In Ethiopia fertilizer recommendations is based on very general crop specific guidelines or more often, a single recommendation for all crops (100 kg DAP (18-46-0) and $100 \mathrm{~kg}$ Urea (46-0-0). Urea and DAP (diammonium phosphate) are the only fertilizer sources that have been in use for the past four decades in the country (IFDC, 2015). This blanket recommendation often fails to take into consideration differences in resource endowment (soil type, labor capacity, climate risk) or make allowances for dramatic changes in input/output price ratio, thereby discouraging farmers from fertilizer application. Moreover, the nutrients in the blanket recommendation are not well balanced agronomically and its continued use will gradually exhaust soil nutrient reserves. According to those sources, urea and DAP (diammonium phosphate) are the only fertilizers imported into the country since 1971. Urea is chemically composed of $46 \%$ of N, while DAP contains $18 \%$ of $\mathrm{N}$ and $46 \%$ of P (National Fertilizer Industry Agency, 2001).

Therefore, neither yields nor profits can be sustained using imbalanced application of fertilizers, as the practice results in accelerating deficiencies of other soil nutrients. Since absence of one or more nutrients besides $\mathrm{N}$ and $\mathrm{P}$ can depress yield significantly. This could explain, in part, the modest crop yield improvements observed over the last few decades in contrast to significant increases in fertilizer use and investment made in the country. Today, in addition to $\mathrm{N}$ and $\mathrm{P}, \mathrm{S}, \mathrm{B}$ and $\mathrm{Zn}$ deficiencies are widespread in Ethiopian soils, while some soils are also deficient in $\mathrm{K}, \mathrm{Cu}, \mathrm{Mn}$ and $\mathrm{Fe}$ (Laekemariam, 2016; Asgelil et al., 2007). 
Mineral fertilizers containing N, P, K and S not only increase crop yield but also improve nutritional quality of crop yields, such as protein, oil, starch, essential amino acids and vitamins in pulses, oil seeds, tubers, and vegetables respectively (Wang et al., 2008).

To overcome the constraint Balanced fertilizers containing N, P, K, S, B and $\mathrm{Zn}$ in blend form are recommended ameliorating site specific nutrient deficiencies and thereby increasing productivity (ATA, 2014). Although there is general perception that the new fertilizer blends are better than the traditional fertilizer recommendation (urea and DAP), their comparative advantages are not explicitly examined and understood under various production environments.

This review part was mainly focused on the newly blended fertilizers and its response on yield and yield components of different field crop and horticultural crops that was conducted recently in some parts of the country.

\section{RESPONSE OF BLENDED FERTILIZERS ON TEF (ERAGRostis TeF (ZuCC) TrotTER)}

There was a significant plant height, shoot length per plant, panicle length per plant, number of tillers per plant, number of spicks per panicle and weight of seeds per panicle at maturity stage than convectional fertilizer Dap and Urea and also control plots. Whereas, application of blended fertilizer and row planting method has brought a significant effect in the Eragrostis tef yield and yield components grown on vertisols (Lemlem et al., 2015).

As the rates of $\mathrm{N}$ and blended fertilizers increased the number of total tillers, productive tillers, aboveground dry biomass yield, grain yield and nutrient uptake of $\mathrm{N}, \mathrm{S}, \mathrm{Zn}$ and B were increased. The economic analysis showed that combined application of $100 \mathrm{~kg}$ blended fertilizer ha ${ }^{-1}$ supplemented with $92 \mathrm{~kg} \mathrm{~N} \mathrm{ha}^{-1}$ provided relatively high net benefit and hence these could be the best rate to apply. The treatment $(92 \mathrm{~kg} \mathrm{~N}+100 \mathrm{~kg}$ NPSZnB kg ha-1) showed high marginal rate of return, high net benefit and relatively small total cost of production for tef production (Teshome, 2018). Similarly Tekle and Wassie (2018) reported that the blended fertilizer provide significantly higher yield components and yield of tef in Tembaro district as compared with conventional $\mathrm{N}$ and $\mathrm{P}$ fertilizers. The maximum economical return recorded from the blended fertilizes (127 NPSZnB + 90 Urea) kg${ }^{1}$ (Table 1).

Table1. Partial budget analysis data of treatment effect on tef at Tembaro district

\begin{tabular}{lccccccc}
\hline & \multicolumn{7}{c}{ Treatments } \\
\cline { 2 - 8 } Variables & C & NP & NPKSZnB & NPS & NPKSB & NPSB & NPSZnB \\
\hline Average yield $\left(\mathrm{kgha}^{-1}\right)$ & 811 & 1632.2 & 2493.3 & 2500 & 2733.3 & 2933.3 & 3122.2 \\
Adjusted yield $\left(\mathrm{kgha}^{-1}\right)$ & 729.9 & 1469.0 & 2244.0 & 2250.0 & 2460.0 & 2640.0 & 2810.0 \\
Gross benefit (ETB) & 12773.3 & 25707.2 & 39269.5 & 39375.0 & 43049.5 & 46199.5 & 49174.7 \\
Cost of Urea-N & 0 & 1600 & 0 & 0 & 0 & 0 & 0 \\
Cost of TSP-P & 0 & 4000 & 0 & 0 & 0 & 0 & 0 \\
Cost of Blended fertilizers & 0 & 0 & 2816 & 2936 & 3488 & 3820 & 4100 \\
Total Variable Cost & 0 & 5600 & 2816 & 2936 & 3488 & 3820 & 4100 \\
Net Benefit (Birr) & 12773.3 & 20107.2 & 36453.5 & 36439.0 & 39561.5 & 42379.5 & 45074.7 \\
\hline MRR (\%) & - & 1.31 & - & D & 5.6 & 8.5 & 9.6 \\
\hline
\end{tabular}

Source: Tekle and Wassie (2018)

\section{RESPONSE OF BLENDED FERTILIZERS ON MAIZE (ZEA MAYS L.)}

Dagne (2016) observed that the maximum mean grain yield $\left(8399.7 \mathrm{~kg} \mathrm{ha}^{-1}\right)$, stover yield $(8553.1 \mathrm{~kg}$ $\mathrm{ha}^{-1)}$ and total biomass yield $\left(16867.7 \mathrm{~kg} \mathrm{ha}^{-1}\right)$ were recorded from blended fertilizers, whereas the lowest were recorded for the control (Table 2). Also yield per unit application of $\mathrm{N}$ of blended fertilizer with $\mathrm{Cu}$ and $\mathrm{Zn}$ was superior to all the treatments. Accordingly, the highest agronomic efficiency of $\mathrm{N}$ was obtained by the blended fertilizer with $\mathrm{Cu}$ and $\mathrm{Zn}$ and the least was recorded for control at both sites. Despite field experiment was conducted on maize with the treatments blended fertilizer and lime for three consecutive cropping seasons on acid Nitisols of Jimma Kersa woreda. Whereas the result revealed that blended fertilize and lime increase yield significantly in all seasons and yield difference observed compare to recommended fertilizer (Table 3) (Jafar, 2018).

Table2. Mean of grain, Stover and total biomass yields of maize 
Response of Blended Fertilizers on the Yield and Yield Components of some Horticultural and Field Crops in the Case of Ethiopia: A Review

\begin{tabular}{lllllll}
\hline \multirow{2}{*}{ Treatments } & \multicolumn{2}{l}{ Grain yield $\left(\mathrm{kgha}^{-1}\right)$} & \multicolumn{2}{l}{ Stover yield $\left(\mathbf{k g h a}^{-1}\right)$} & \multicolumn{2}{l}{ Total biomass yield $\left(\mathbf{k g h a}^{-1}\right)$} \\
\cline { 2 - 7 } & Kejo & Ongobo & Kejo & Ongobo & Kejo & Ongobo \\
\hline Control & $1750.3^{\mathrm{c}}$ & $1953.9^{\mathrm{c}}$ & $2875.2^{\mathrm{c}}$ & $2824.8^{\mathrm{c}}$ & $4625.5^{\mathrm{c}}$ & $4778.7^{\mathrm{c}}$ \\
Rec. NP & $7425.9^{\mathrm{b}}$ & $7858.9^{\mathrm{b}}$ & $7710.1^{\mathrm{b}}$ & $7630.5^{\mathrm{b}}$ & $15136.0^{\mathrm{b}}$ & $15489.4^{\mathrm{b}}$ \\
Rec. NP $+\mathrm{Cu}+\mathrm{Zn}$ & $7532.2^{\mathrm{b}}$ & $7930.4^{\mathrm{b}}$ & $7825.2^{\mathrm{b}}$ & $7725.1^{\mathrm{b}}$ & $15357.4^{\mathrm{b}}$ & $15655.5^{\mathrm{b}}$ \\
Ble. Fer & $8000.9^{\mathrm{a}}$ & $8233.0^{\mathrm{a}}$ & $8411.0^{\mathrm{a}}$ & $8389.0^{\mathrm{a}}$ & $16411.9^{\mathrm{a}}$ & $16622.0^{\mathrm{a}}$ \\
Ble. fer $+\mathrm{Cu}+\mathrm{Zn}$ & $8103.0^{\mathrm{a}}$ & $8399.7^{\mathrm{a}}$ & $8553.1^{\mathrm{a}}$ & $8468.0^{\mathrm{a}}$ & $16656.1^{\mathrm{a}}$ & $16867.7^{\mathrm{a}}$ \\
LSD $(0.05)$ & 151.80 & 188.74 & 435.35 & 347.22 & 688.49 & 664.22 \\
CV $(\%)$ & 1.50 & 1.78 & 4.00 & 3.22 & 3.28 & 3.11 \\
SE $( \pm)$ & 49.26 & 61.24 & 141.28 & 112.68 & 223.42 & 215.55 \\
\hline
\end{tabular}

Source: Dagne (2016)

Table3. Blended fertilizer and limed on Mean Grain Yield Kg Over years (2015-2017) and \% mean Maize grain yield $\left(\mathrm{kgha}^{-1}\right)$ increment over Control and Recommended NP fertilizer

\begin{tabular}{|c|c|c|c|c|c|c|}
\hline \multirow{2}{*}{ Treatment } & \multicolumn{3}{|c|}{ Mean G Yield Kg/ha } & \multirow{2}{*}{$\begin{array}{c}\text { Over year } \\
\text { mean G } \\
\text { Yield } \\
\text { Kg/ha }\end{array}$} & \multirow{2}{*}{$\begin{array}{c}\text { \% G Yield } \\
\text { increments } \\
\text { over } \\
\text { Recommended } \\
\text { NP }\end{array}$} & \multirow{2}{*}{$\begin{array}{c}\text { \% G Yield } \\
\text { increments } \\
\text { over } \\
\text { Recommended } \\
\text { NP }\end{array}$} \\
\hline & 2015 & 2016 & 2017 & & & \\
\hline Control & 3129 & 1008 & 3972 & 2703 & - & \\
\hline Recommended NP & 6162 & 4494 & 6636 & 5764 & 113 & 3 \\
\hline NPSB & 6585 & 4522 & 6788 & 5965 & 121 & 3 \\
\hline NPSZnB & 6697 & 4305 & 7248 & 6083 & 125 & 6 \\
\hline Modified NPSZnB & 6549 & 5199 & 6565 & 6104 & 126 & 6 \\
\hline NPKSZnB & 5888 & 5184 & 5857 & 5643 & 109 & -2 \\
\hline Control+Lime & 3483 & 1244 & 3294 & 2673 & - & \\
\hline Recommended NP & 6723 & 5657 & 5990 & 6123 & 129 & \\
\hline NPSB+Lime & 6798 & 6358 & 7000 & 6719 & 100 & 10 \\
\hline NPSZnB+Lime & 7583 & 5411 & 6526 & 6507 & 143 & 6 \\
\hline Modified NPSZnB+Lime & 6997 & 5279 & 6611 & 6296 & 135 & 3 \\
\hline NPKSZnB+Lime & 7167 & 5648 & 7109 & 6641 & 148 & 8 \\
\hline
\end{tabular}

Source: Jafar (2018)

\section{RESPONSE OF BLENDED FERTILIZERS ON SORGHUM (SORGHUM BICOLOR (L.) MOENCH)}

The experiment was conducted at the experimental station of Shire-Mytsebri Agricultural Research Center (SMARC) at Sheraro sub-site. The result revealed that nitrogen, phosphorus and potassium uptake by grain and stalk were significant difference among fertilizers treatments. The maximum $\mathrm{N}$ uptake by grain $\left(38.56 \mathrm{~kg} \mathrm{ha}^{-1}\right)$ and stalk $\left(37.28 \mathrm{~kg} \mathrm{ha}^{-1}\right), \mathrm{P}$ uptake by grain $\left(26.50 \mathrm{Kg} \mathrm{ha}^{-1}\right)$ and stalk $\left(23.02 \mathrm{Kg} \mathrm{ha}^{-1}\right)$ uptake of grain $\left(28.84 \mathrm{Kg} \mathrm{ha}^{-1}\right)$ and stalk $\left(40.00 \mathrm{Kg} \mathrm{ha}^{-1}\right)$ was recorded from plot treated by NPKSZn fertilizer. Similarly the maximum total (Grain + Stalk) nutrients uptake were recorded from the NPKSZn treated plots (Table 4). Finally the results conclude that NPKSZn blended fertilizer can be recommended for increased sorghum productivity particularly in the study area because it improved sorghum plant nutrient uptake and yield production (Redai et al., 2018).

\section{RESPONSE OF BLENDED FERTILIZERS ON DURUM WHEAT (TRITICUM AESTIVUM L.)}

The responses of blended fertilizer on durum wheat (Triticum aestivum L.) were conducted on two varieties Wane and Kingbird. The numbers of productive tillers per plant were significantly affected by the interaction effect of varieties and fertilizer rates. The result showed that the maximum number of productive tiller (7.7) and (6) were recorded from $300 \mathrm{~kg}$ NPSB + $100 \mathrm{~kg}$ Urea ha Wane and Kingbird varieties respectively. The highest result of Wane and Kingbird verities were improved by $42.9 \%$ and $26.7 \%$ respectively as compared to the lowest number of productive tillers per plant at control (Rut-Duga et al., 2019).

The activity conducted blended fertilizer with bread wheat variety Danda'a showed that the grain yield, straw yield and above ground dry biomass was highly significantly affected by the blended fertilizers. The maximum grain yield $\left(5.77 \mathrm{t} \mathrm{ha}^{-1}\right)$, straw yield $\left(8.52 \mathrm{t} \mathrm{ha}^{-1}\right)$ and above ground dry 
biomass $\left(14.29 \mathrm{t} \mathrm{ha}^{-1}\right)$ were recorded from the treatment NPSBZn $\left(175 \mathrm{~N}+125 \mathrm{P}_{2} \mathrm{O}_{5}+11.1 \mathrm{~S}+3.3 \mathrm{~B}\right.$ and $0.15 \mathrm{Zn}$ ) Kg ha- ${ }^{-1}$ rate. This might be due to the combined effect of nutrients like N, P, S, Zn and B in blended fertilizer which might have boosted growth and development of crop compared as compared to the control plots (Abebual et al., 2019).

(Abebaw and Hirpa, 2018) reported that, application of blended fertilizer $200 \mathrm{~kg}$ blended fertilizer + $63.91 \mathrm{~kg}$ of urea /ha gives the maximum grain yield as compared to control and NP recommended rates. Despite that blended and urea fertilizer application with row planting yield can increase by $38 \%$ over the blanket fertilizer recommendation of DAP and urea.

\section{RESPONSE OF BLENDED FERTILIZERS ON CHICKPEA (CICER ARIENTINUM L.)}

Research reports indicate that productivity of chickpea is below potential due to low soil fertility and little use of soil amendment practices, especially low use of mineral fertilizers. Four levels of blended NPSZnB fertilizer (0, 64.4, 129 and $193 \mathrm{~kg}$ ha-1) with standard check (100 kg DAP $\mathrm{ha}^{-1}$ ) and four chickpea varieties (Natoli, Dalota, Arerti and Dhera) the result revealed that blended NPSZnB fertilizer significantly affected most of the agronomic parameters (China, 2018).

Despite an application of $193 \mathrm{~kg} \mathrm{NPSZnB} \mathrm{ha}^{-1}$ shortened days to flowering (49.33) and physiological maturity (99.3) Similarly, chickpea responses were maximum at $193 \mathrm{~kg} \mathrm{NPSZnB} \mathrm{ha}^{-1}$ resulted in the highest number of primary branches (3.442 plant $\left.{ }^{-1}\right)$, total number of nodules (32.81 plant $\left.^{-1}\right)$, aboveground biomass (6494 $\left.\mathrm{kg} \mathrm{ha}^{-1}\right)$, seed yield $\left(3187 \mathrm{~kg} \mathrm{ha}^{-1}\right)$ and straw yield (3308 $\left.\mathrm{kg} \mathrm{ha}^{-1}\right)$ Generally significantly increased and optimum growth, yield, and yield components were obtained already in response to the application of $193 \mathrm{~kg} \mathrm{NPSZnB} \mathrm{ha}^{-1}$, which were statistically in parity with the standard fertilizer practice of applying $100 \mathrm{~kg}^{\mathrm{DAP}} \mathrm{ha}^{-1}$ (China, 2018).

\section{RESPONSE OF BLENDEd FERTILIZERS ON COMMON BEAN (PHASEOLUSE VUlGaRis L.)}

The research activity conducted at Hawassa dume in the Meskan districts of South Ethiopia showed there was significant response observed in growth, yield and yield components blended fertilizer application level of $100 \mathrm{~kg} / \mathrm{ha}$. The economic analysis shows the highest net benefit was obtained from $100 \mathrm{~kg}$ NPSZnB per hectare with highest marginal rate of return $(12.78 \%)$ (Lake and Jemaludin, 2018).

\section{RESPONSE Of BLENDEd FERTILIZERS ON SUgARCANE (SACCHARUM OFFICINARUM L.)}

Application of balanced fertilizers could be the basis to produce more crop output from existing land under cultivation and nutrient needs of crops according to their physiological requirements and expected yields (Ryan, 2008). This can be achieved by application of blended fertilizers, the mechanical mixture of two or more granular fertilizer materials containing $\mathrm{N}, \mathrm{P}, \mathrm{K}$ and other essential plant nutrients such as $\mathrm{S}, \mathrm{Zn}$, and B.

Dereje et al. (2018) reported that blended fertilizer treatment with the rate of $\left(250 \mathrm{~kg} \mathrm{ha}^{-1} \mathrm{blended}^{+}\right.$ $94 \mathrm{~kg} \mathrm{~N}$ ) ha ${ }^{-1}$ at one month after harvest resulted in higher ratoon cane weight per stalk, stalk girth, cane yield, sugar yield, node length, stalk population and node number on sugarcane plant.

Table4. The effect of fertilizer treatments on nutrient uptake of sorghum

\begin{tabular}{|c|c|c|c|c|c|c|c|c|c|}
\hline \multirow{3}{*}{ Treatments } & \multicolumn{9}{|c|}{ Nutrient uptake (kgha-1) } \\
\hline & \multicolumn{3}{|c|}{ Nitrogen } & \multicolumn{3}{|c|}{ Phosphorus } & \multicolumn{3}{|c|}{ Potassium } \\
\hline & Grain & Stalk & Total & Grain & Stalk & Total & Grain & Stalk & Total \\
\hline $\mathrm{N}$ & $15.14 \mathrm{e}$ & $17.32 \mathrm{~d}$ & $32.46 \mathrm{e}$ & $8.80 \mathrm{f}$ & $8.37 \mathrm{e}$ & $17.16 \mathrm{f}$ & $11.24 \mathrm{~d}$ & $17.62 \mathrm{~d}$ & $28.85 \mathrm{e}$ \\
\hline $\mathrm{P}$ & $13.37 \mathrm{e}$ & $14.75 \mathrm{~d}$ & $28.13 \mathrm{f}$ & $10.68 \mathrm{e}$ & $10.03 \mathrm{~d}$ & $20.71 \mathrm{e}$ & $12.04 \mathrm{~d}$ & $20.88 \mathrm{~cd}$ & $32.92 \mathrm{e}$ \\
\hline NP & $27.42 \mathrm{~d}$ & $25.53 \mathrm{c}$ & $52.95 \mathrm{~d}$ & $16.48 \mathrm{~d}$ & $15.29 \mathrm{c}$ & $31.76 \mathrm{~d}$ & $21.20 \mathrm{bc}$ & $26.95 \mathrm{bc}$ & $48.14 \mathrm{~d}$ \\
\hline NPK & $34.78 b$ & $35.69 \mathrm{a}$ & $70.46 \mathrm{~b}$ & $23.16 \mathrm{~b}$ & $22.30 \mathrm{a}$ & $45.45 \mathrm{~b}$ & $27.45 \mathrm{a}$ & $38.68 \mathrm{a}$ & $66.13 \mathrm{ab}$ \\
\hline NPS & $28.51 \mathrm{~d}$ & $30.93 \mathrm{~b}$ & $59.45 \mathrm{c}$ & $17.91 \mathrm{~cd}$ & $17.10 \mathrm{~b}$ & $35.01 \mathrm{c}$ & $19.96 \mathrm{c}$ & $33.73 \mathrm{ab}$ & $53.69 \mathrm{~cd}$ \\
\hline NPKS & $29.30 \mathrm{~cd}$ & $29.09 \mathrm{~b}$ & $58.39 \mathrm{c}$ & $17.96 \mathrm{~cd}$ & $17.59 \mathrm{~b}$ & $35.55 \mathrm{c}$ & $21.71 \mathrm{bc}$ & $33.82 \mathrm{ab}$ & $55.53 \mathrm{~cd}$ \\
\hline NPKSZn & $38.56 \mathrm{a}$ & $37.28 \mathrm{a}$ & $75.84 \mathrm{a}$ & $26.50 \mathrm{a}$ & $23.02 \mathrm{a}$ & $49.52 \mathrm{a}$ & $28.84 \mathrm{a}$ & $40.00 \mathrm{a}$ & $68.84 \mathrm{a}$ \\
\hline NPKSZnB & $30.89 c$ & $29.07 \mathrm{~b}$ & $59.95 \mathrm{c}$ & $19.05 \mathrm{c}$ & $18.12 \mathrm{~b}$ & $37.17 \mathrm{c}$ & $24.04 \mathrm{~b}$ & $33.44 \mathrm{ab}$ & $57.48 \mathrm{c}$ \\
\hline NPKSZnB(ATA) & $28.35 d$ & $28.35 \mathrm{~b}$ & $56.71 \mathrm{c}$ & $17.95 \mathrm{~cd}$ & $17.77 \mathrm{~b}$ & $35.71 \mathrm{c}$ & $22.51 \mathrm{bc}$ & $36.03 \mathrm{a}$ & $58.55 \mathrm{bc}$ \\
\hline Control & $10.16 \mathrm{f}$ & $15.28 \mathrm{~d}$ & $25.45 \mathrm{f}$ & $6.01 \mathrm{~g}$ & $7.31 \mathrm{e}$ & $13.32 \mathrm{~g}$ & $8.26 \mathrm{e}$ & $16.68 \mathrm{~d}$ & $24.94 \mathrm{e}$ \\
\hline SEM & 0.756 & 0.982 & 1.265 & 0.554 & 0.557 & 0.743 & 0.917 & 2.500 & 2.683 \\
\hline LSD & 2.165 & 2.813 & 3.621 & 1.587 & 1.595 & 2.127 & 2.627 & 7.15 & 7.682 \\
\hline Significance & $* 8 *$ & $* 8 *$ & $* * *$ & $* * *$ & $* 8 *$ & $* 8 *$ & $* * *$ & $* * *$ & $* 8 *$ \\
\hline
\end{tabular}

Means sharing the same letter do not differ significantly at $\mathrm{P} \leq 0.05$ according to the LSD test Redailet al. (2018) 


\section{Response Of BLENDEd FERTILIZERS ON Hot PEPPER (CAPSICUM ANNUUM L.)}

Soil fertility decline and a resultant nutrient deficiency is the most yield limiting factor for vegetable production including hot pepper in different agro-ecologies of Ethiopia, of them the major limiting ones are $\mathrm{N}, \mathrm{P}$ and other macro and micronutrients such as $\mathrm{K} \mathrm{S}, \mathrm{B}$ and $\mathrm{Zn}$ deficiencies (Alemu and Ermias, 2000). Application of blended fertilizer showed significant diference among the treatments. The maximum plant height $67.33 \mathrm{~cm}$, number of primary branches 3.33 and secondary branches 6.93 was observed from application of blended fertilizers rate at $150 \mathrm{~kg}$ NPSB $+42 \mathrm{~kg} \mathrm{~N}$ ha $^{-}$ ${ }^{1}$ and $150 \mathrm{~kg}$ NPSBZn $+44 \mathrm{~kg} \mathrm{~N}^{-1}{ }^{-1}$ respectively as compared to the recommended NP fertilizers and the control (Table 3) (Nimona et al.,2018)

Nimona et al. (2018) reported that the marketable hot pepper pod yield was significantly affected by blended fertilizer rates. The results showed that the highest marketable pod yield $\left(2.22 \mathrm{t} \mathrm{ha}^{-1}\right)$ was obtained from plots treated with blended fertilizer rate of $150 \mathrm{~kg} \mathrm{NPSBZn}+44 \mathrm{~kg} \mathrm{~N}$ ha- ${ }^{1}$.

Table5. Effect of blended fertilizers type and rates on plant height, number of primary and secondary branches of hot pepper at Assosa, western Ethiopia

\begin{tabular}{|c|c|c|c|}
\hline Treatment (kg ha $\left.{ }^{-1}\right)$ & PH & NPB & NSB \\
\hline Control & $49.47^{\mathrm{d}}$ & $2.47^{\mathrm{d}}$ & $4.27^{\mathrm{d}}$ \\
\hline Recommended NP & $57.33^{c}$ & $2.8^{\mathrm{c}}$ & $5.73^{c}$ \\
\hline $100 \mathrm{NPSB}+28 \mathrm{~N}$ & $63.07^{\mathrm{ab}}$ & $3.07^{\mathrm{b}}$ & $5.87^{c}$ \\
\hline 150 NPSB $+42 \mathrm{~N}$ & $66.4^{a b}$ & $3.33^{a}$ & $6.47^{\mathrm{ab}}$ \\
\hline $200 \mathrm{NPSB}+56 \mathrm{~N}$ & $62.13^{a b c}$ & $3.0^{\mathrm{bc}}$ & $5.93^{\mathrm{bc}}$ \\
\hline 100 NPSBZn $+29 N$ & $61.07^{\mathrm{bc}}$ & $3.00^{\mathrm{bc}}$ & $5.87^{c}$ \\
\hline 150 NPSBZn $+44 N$ & $67.33^{\mathrm{a}}$ & $3.13^{a b}$ & $6.93^{\mathrm{a}}$ \\
\hline 200 NPSBZn $+58 \mathrm{~N}$ & $62.53^{a b c}$ & $3.07^{\mathrm{b}}$ & $6.07^{\mathrm{bc}}$ \\
\hline LSD (0.05) & 5.591 & 0.204 & 0.5694 \\
\hline $\mathrm{CV}(\%)$ & 5.22 & 3.91 & 5.52 \\
\hline
\end{tabular}

$\mathrm{PH}=\mathrm{Plant}$ height; NPB=Number of primary branches; NSB=Number of secondary branches; NPSBZn| are fertilizer that contains nitrogen, phosphorous, sulfur, boron and zinc; CV=Coefficient variance; LSD= List significance difference. Nimona et al. (2018)

\section{Response Of BLended Fertilizers on Sweet Potato (IPOMOEa Batatas (L.) LAM) AND Potato (SOLANUM TUbEROSUM L.)}

Getachew (2018) reported that blended fertilizer responded to sweet potato verities. An application of $159 \mathrm{~kg} \mathrm{ha}^{-1}$ NPSB fertilizer rate is economical and recommended for sweet potato varieties production under Jimma and its vicinity of Southwest Ethiopia. The dry matter increased from 24.23 to $33.48 \%$; 25 to $35 \%$ as NPSB increased from 0 to $159 \mathrm{~kg} \mathrm{ha}^{-1}$ with Kulfo and Tulla, varities respectively and from 22.07 to $30.52 \%$ in Guntutie, as NPSB increased from 0 to $214 \mathrm{~kg} \mathrm{ha}^{-1}$ which implies the same flow in Starch content. The analyzed partial budget for average of 15 treatments was resulted in highest MRR at Guntutie, Kulfo and Tulla X $159 \mathrm{~kg} \mathrm{ha}^{-1}$ blended fertilizer with 805.19\%, 577.76\% and 573.41, respectively.

Means of marketable fresh storage root yield ton per hectare and mean storage root girth with the same variety that received the same NPSB level were resulted in significant different. These tested varieties with $159 \mathrm{~kg} \mathrm{ha}^{-1}$ blended fertilizer were resulted in high yield Kulfo scored $39.41 \%$, Tulla scored $34.2 \%$ and Guntutie scored $47.7 \%$ total yield advantage over the control (Getachew, 2018).

On the other hand Potato growth parameter and yield was significantly affected by NPS blended fertilizer $\left(150 \mathrm{~kg} \mathrm{ha}^{-1}\right)$ gave the maximum main stem number of 8.5 and dry matter content $(23.5 \%)$ respectively (Fig 1) (Amin, 2018). 


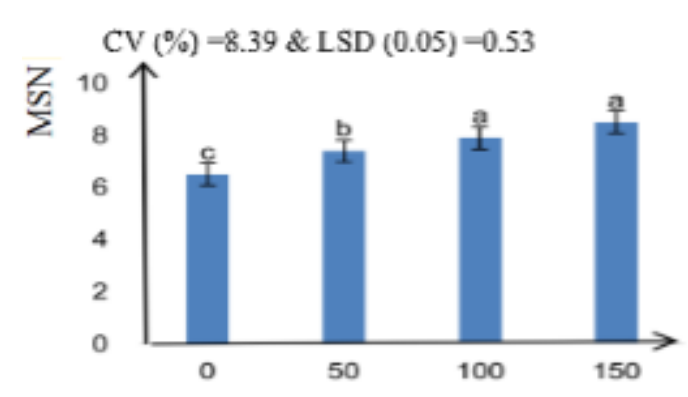

(a) NPS blended fertilizer $\mathrm{kg}$ ha

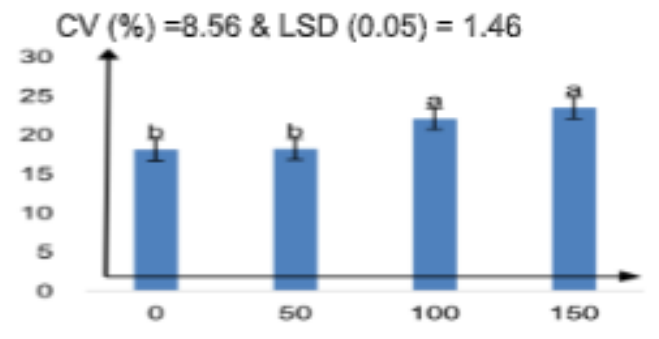

(b) NPS blended fertilizer kg ha' $^{-1}$

Fig1. Effects of NPS blended fertilizer on (a) Main Stem Number of potatoes and (b) Dry Matter Content of potato tuber Amin (2018)

\section{CONCLUSION}

Recent soil inventory by EthioSIS (Ethiopian Soil Information System) revealed that in addition to N and $\mathrm{P}$, nutrients such as $\mathrm{S}, \mathrm{B}$, and $\mathrm{Zn}$ are deficient in different areas of the country. However, yields have not increased as expected even when recommendation rates of $\mathrm{N}$ and $\mathrm{P}$ fertilizers applied. This is mainly due to use of two types of fertilizers (DAP and urea) alone and this may cause unbalanced fertilizers use.

Different research activity was conducted on the response of blended fertilize on tef, maize, Sorghum, durum wheat, chickpea, common bean, sugarcane, hot pepper sweet potato and potato crops in different parts of the country. Whereas blended fertilizer improved the Yield related traits, yield and also economical acceptable as compared with the previous convectional fertilizers (DAP and urea). Generally soil test based recommended a blended fertilizer usage provides macro and micro nutrients that was needed by the crop to provide the maximum yield and which was economically feasible for the growers.

\section{REFERENCES}

[1] Abebaw Tadele Alem and Hirpa Legese, 2018. Effects of fertilizer rate (blended) and sowing methods on yield of bread wheat (Triticum aestivum) and its economic profitability in Western Ethiopia. Journal of Comprehensive Research in Biological Sciences 5(7):1-14.

[2] Abebual Woldetsadik, Wondwosen Tena and Asmare Melese, 2019. Effect of Different Blended Fertilizer Formulation on Yield and Yield Components of Bread Wheat (Triticum aestivum L.) in Siyadebrenawayu District, North Shewa, Ethiopia. Journal of Biology, Agriculture and Healthcare 9 (15): 13-23.

[3] Alemu $\mathrm{H}$ and Ermias A, 2000. Horticultural crops production and associated constraints in North-west Ethiopia. Working Paper. Agricultural Economics Research Division, Agricultural Research Centre, Adet.;18.

[4] Amin Ababiya, 2018. Integrated Use of Nps Blended Fertilizer And Cattle Manure For Growth, Yield And Quality of Potato (Solanum Tuberosum L.) Under Dabo Ghibe, Kebele, Seka Werada of Jimma Zone, Southwest Ethiopia Msc thesis. Jimma University College of Agriculture and Veterinary Medicine, PP.66.

[5] Asgelil D, Taye B and Yesuf A, 2007. The status of micro-nutrients in Nitisols, Vertisols, Cambisols and Fluvisols in major maize, wheat, teff and citrus growing areas of Ethiopia. In: Proceedings of Agricultural Research Fund Research Projects Completion Workshop held on 1-2 February 2007 at EIAR, Addis Ababa, Ethiopia. pp 77-96.

[6] ATA (Agricultural Transformation Agency), 2014. Soil Fertility Status and Fertilizer Recommendation Atlas for Tigray Regional State, Ethiopia. Ethiopian Agricultural Transformation Agency (ATA), A.A., Ethiopia.

[7] China Gebru, 2018. Response Of Chickpea (Cicer Arientinum L.) Varieties To Blended Npsznb Fertilizer Application In Ada'a-Liban District, Central Ethiopia Msc Thesis Haramaya University Pp95

[8] Dagne Chimdessa, 2016. Blended Fertilizers Effects on Maize Yield and Yield Components of Western Oromia, Ethiopia. Journal of Agriculture, Forestry and Fisheries. Vol. 5(5):151-162.

[9] Dereje Legesse Hirpa Legesse and Negash Geleta, 2016. Effects of Blended Fertilizer Rate and Time of Application on Growth and Yield of Sugarcane Ratoon Crop at Arjo-Sugar Factory, Western Ethiopia Science, Technology and Arts Research Journal 5(1): 1-8. 
[10] Getachew Etana, 2018. Effect of NPSB Blended Fertilizer on Growth, Yield And Quality of Orange Fleshed Sweet Potato (Ipomoea batatas (L.) Lam) Varieties under Jimma Condition, South West Ethiopia. MSc. Thesis Jimma University College of Agriculture And Veterinary Medicine pp74.

[11] IFDC (International Fertilizer Development Center), 2015. Assessment of Fertilizer Consumption and Use by Crop in Ethiopia https://africafertilizer.org/wp-content/uploads/2017/05/FUBC-Ethiopia-Final-Report2016.pdf

[12] Jafer Dawid, 2018. Validation of Blended Fertilizer for Maize Production Under Limed Condition of Acid Soil Journal of Natural Sciences Research 8 (23): 52 -58.

[13] Laekemariam Fanuel, 2016. Soil nutrient status of smallholder cassava farms in southern Ethiopia. Journal of Biology, Agriculture and Healthcare, 6(19), pp.12-18.

[14] Lake Mekonnen and Jemaludin saliha, 2018. The Response of Common Bean (Phaseoluse Vulgaris L.) to Various Levels of Blended Fertilizer. International Journal of Research in Agriculture and Forestry 5(7):15-20.

[15] Lemlem Hiwot, Shimbahri Mesfin and Muruts Hagazi, 2015. Effect of Blended Fertilizer Applicationon (Eragrostistef /Zucc./Trotter) Yield, Yield Component and Nutrient Uptake by Grain Grown on Regosols and Vertisols, North Ethiopia. Journal of Natural Sciences Research 5 (21):13-22.

[16] National Fertilizer Industry Agency, 2001. Agronomic and Environmental Aspects of Fertilizer Use in Ethiopia. National Fertilizer Industry Agency, Addis Ababa, Ethiopia.

[17] Redai Weldegebriel, Tesfay Araya and Yemane G.Egziabher, 2018. Effect of NPK and Blended Fertilizer Application on Nutrient Uptake and Use Efficiency of Selected Sorghum (Sorghum bicolor (L.) Moench) Varieties Under Rain-fed Condition in Sheraro District, Northern Ethiopia. Momona Ethiopian Journal of Science 10(1):140-156.

[18] Rut-Duga D, Diriba-Shiferaw G, and Wogayehu Worku, 2019. Effects of Blended Fertilizer Rates on Bread Wheat (Triticum aestivum L.) Varieties on Growth and Yield Attributes. Journal of Biology, Agriculture and Healthcare 9 (15): 1-12.

[19] Ryan, J., 2008. A perspective on balanced fertilization in the Mediterranean region. Turkish Journal of Agriculture and Forestry. 32(2):79-89.

[20] Tekle Lombamo and Wassie Haile, 2018. Response of Tef (Eragrostis tef (Zucc.) Trotter) to Blended Fertilizers in Tembaro, Southern Ethiopia. Journal of Biology, Agriculture and Healthcare 8 (13): 34-39.

[21] Teshome Mesfin, 2018. Effects Of Nitrogen And Blended Fertilizers On Yield And Yield Components of Tef [(Eragrostis Tef (Zucc.) Trotter] In Ada'a District, Central Highlands of Ethiopia. Msc. Thesis Hawassa University College of Agriculture pp88.

[22] Wang, Z. H., Li, S. X., and Malhi, S. S, 2008. Review effects of fertilization and other agronomic measures on nutritional quality of crops. Journal of the Science of Food and Agriculture 88 (7) - 23.

Citation: Ewnetu Teshale \& Afework Legesse "Response of Blended Fertilizers on the Yield and Yield Components of some Horticultural and Field Crops in the Case of Ethiopia: A Review ", International Journal of Forestry and Horticulture (IJFH), vol. 6, no. 1, pp. 1-7, 2020. Available: DOI: http://dx.doi.org/ 10.20431/ 2454-9428.0601001

Copyright: (c) 2020 Authors. This is an open-access article distributed under the terms of the Creative Commons Attribution License, which permits unrestricted use, distribution, and reproduction in any medium, provided the original author and source are credited. 